\title{
Protective effect of an antimicrobial peptide from Mytilus edulis chilensis expressed in Nicotiana tabacum L.
}

\author{
Gloria Arenas* \\ Laboratorio de Genética e Inmunología Molecular \\ Instituto de Biología \\ Pontificia Universidad Católica de Valparaíso \\ Av. Brasil 2950, Valparaíso, Chile \\ PO Box 4059 \\ Tel: 5632273205 \\ Fax: 5632596703 \\ E-mail: garenas@ucv.cl
}

\section{Sergio H. Marshall}

Laboratorio de Genética e Inmunología Molecular Instituto de Biología

Pontificia Universidad Católica de Valparaíso

Av. Brasil 2950, Valparaíso, Chile

PO Box 4059

Tel: 5632273119

Fax: 5632596703

E-mail: smarshal@ucv.cl

\author{
Valeria Espinoza \\ Centro de Biotecnología "D. Alkalay L." \\ Universidad Técnica Federico Santa-María \\ Av. España1680, Valparaíso, Chile \\ Tel: 5632654730 \\ Fax: 5632654783 \\ E-mail: valeria.espinoza@usm.cl
}

\section{Ingrid Ramírez}

Centro de Biotecnología "D. Alkalay L."

Universidad Técnica Federico Santa-María

Av. España 1680, Valparaíso, Chile

Tel: 5632654730

Fax: 5632654783

E-mail: ingrid.ramirez@usm.cl

\section{Hugo Peña-Cortés}

Centro de Biotecnología "D. Alkalay L."

Universidad Técnica Federico Santa-María

Av. España 1680, Valparaíso, Chile

Tel: 5632654730

Fax: 5632654783

E-mail: hugo.pena@usm.cl

Financial support: This work was supported by Grant PUCV-DI 122-769- Chile.

Keywords: antibacterial peptide, disease resistance, in vivo expression, Nicotiana tabacum L., Pseudomonassyringae pv. syringae, transgenic tobacco plants.

A "defensin-like" antibacterial peptide from Mytilus edulis chilensis, was sub-cloned into a binary vector for expression in plant tissues. The resulting new clone was electroporated into $A$. tumefaciens to transform tobacco plants. The presence of the construct in transgenic tobacco lines was demonstrated through RT-PCR, Northern and Western blots. Transformed positive plants were selected and grown for challenging. Tobacco leaves were infiltrated with Pseudomonassyringae pv. syringae and visual lesions determined at different times post-exposure. Of seven plants exposed, four gave variable protection up to seven days post-infection while one of them appears to be fully protected. These results suggest that defensin-

*Corresponding author 
like antimicrobial peptides from molluscs are a good source to provide resistance of tobacco plants to Pseudomonassyringae pv. syringae.

Antibacterial peptides and proteins are part of the innate response, and as such constitute the first line of defence against microbial infections in most living organisms (Zasloff, 2002; Yeaman, 2003; Tossi, 2005). They have been reported at all levels, from mammals (Ackermann et al. 2004; Bardan et al. 2004) to insects (Otvos Jr., 2000), marine invertebrates (Haug et al. 2004; Tincu and Taylor, 2004) and plants (Castro and Fontes, 2005). Most of these peptides have been successfully cloned, expressed and tested both in vitro and in vivo (Wu et al. 2000; Metlitskaia et al. 2004; Ingham et al. 2005) in their ability to neutralize bacterial infections. At present, more that 500 different molecules have been reported (http://aps.unmc.edu/AP/main.php). In mussels, the defensins constitute the most important peptide family characterized considering their primary structure and their consensus cysteine array (Charlet et al. 1996; Hubert et al. 1996; Mitta et al. 2000; Marshall and Arenas 2003).

In plants, genes encoding defensins are developmentally regulated, with a predominant expression in outer cell layers (Moreno et al. 1994; Terras et al. 1995), and can be induced above basal levels in response to pathogen infection and other stresses (Chiang and Hadwiger, 1991; Moreno et al. 1994; Terras et al. 1995; Penninckx et al. 1996; Epple et al. 1997). Additionally, certain defensin genes are down-regulated by some pathogens (Moreno et al. 1994). Gene expression patterns of defensins (similar to

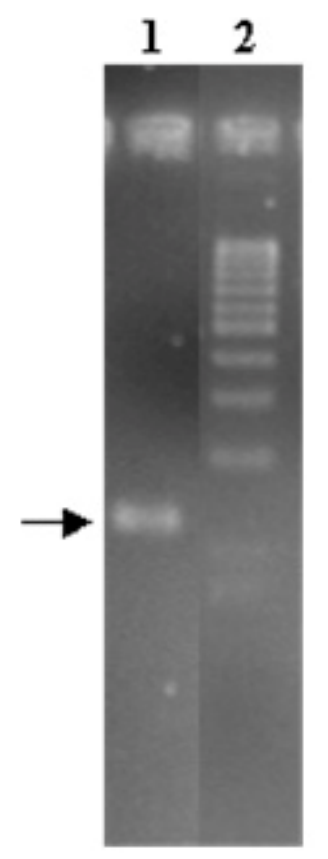

Figure 1. 2.5\% Agarose gel electrophoresis demonstrating the expected size of the defensin-like clone. The $148 \mathrm{bp}$ specific insert (lane 1) was recovered from the amplified vector pCX-TOPO after digestion with Xho1 and BamH1 enzymes. Lane 2, 100 bp ladder. plant thionines) are thus consistent with a hypothetical role in plant defence (Broekaert et al. 1995; Broekaert et al. 1997).

There are a number of reports demonstrating the expression of heterologous antimicrobial peptides in plants with different degrees of success (Huang et al. 1997). The most abundant are those relating transferring these molecules from plant to plant (Sharma et al. 2000; Kanzaki et al. 2002). Notwithstanding, there are a few reporting transgenic expression of peptides derived from insect and amphibians (Sharma et al. 2000; Ponti et al. 2003). In this report, we demonstrate the protective expression of a defensin-like gene from Mytilus edulis chilensis as a stable transgene in Nicotiana tabacum plants when challenged with the phytopathogen Pseudomonassyringae pv. syringae.

\section{MATERIALS AND METHODS}

\section{Clone description}

The 148 bp fragment was obtained from genomic DNA from Mytilus chilensis using a set of degenerateprimers constructed upon the DNA sequence from Mytilus galloprovincialis (Mitta et al. 1999). The pair of primers which efficiently amplified the putative gene was: SEN-A, 5'-CCGCATCKATACCANGTRCANC-3'and ANT- A2, 3'-CCGCATCKATARCANGTRCANCT-5'. The amplified sequence was cloned into pCX-TOPO, a maintenance vector described elsewhere (Topo TA Cloning, Instruction Manual, Version P 051302. 25-0184, Invitrogen, USA).

\section{Construction of the expression vector}

The pCX-TOPO-containing clone was digested with Xho1 and BamH1 enzymes to release the defensin-like coding sequence. Prior to cloning the target sequence into the pBinAR plant tissue expression vector (Rocha-Sosa et al. 1989), the fragmentwas subcloned in the intermediate vector $\mathrm{pBS}$ in order to leave the target sequence in a "sense" orientation under the control of the $35 \mathrm{~S} \mathrm{CaMV}$ promoter. pBS was linearized with Xho1 and BamH1, ligated with the defensin ORF, and positive clones detected through agarose gel electrophoresis. Restriction with Kpn 1 $-X b a 1$ enzymes released the coding sequence from the pBS vector which was exposed to the already Kpn $1-X b a 1$ linearized pBinAR vector. Ligation resulted in the recombinant expression vector. Positive clones (MCh-Def) were selected through standard bacterial transformation and restriction gel analysis as well as transformation and selection into Agrobacterium tumefaciens.

\section{Agrobacterium tumefaciens-mediated plant transformation}

The prepared construct MCh-Def was introduced in $A$. tumefaciens strain $\mathrm{C} 58 \mathrm{C} 1$ containing plasmid pGV2260 (Deblaere et al. 1985) via electroporation. Transformation of tobacco (Nicotiana tabacum var. Xanhi NN) was 


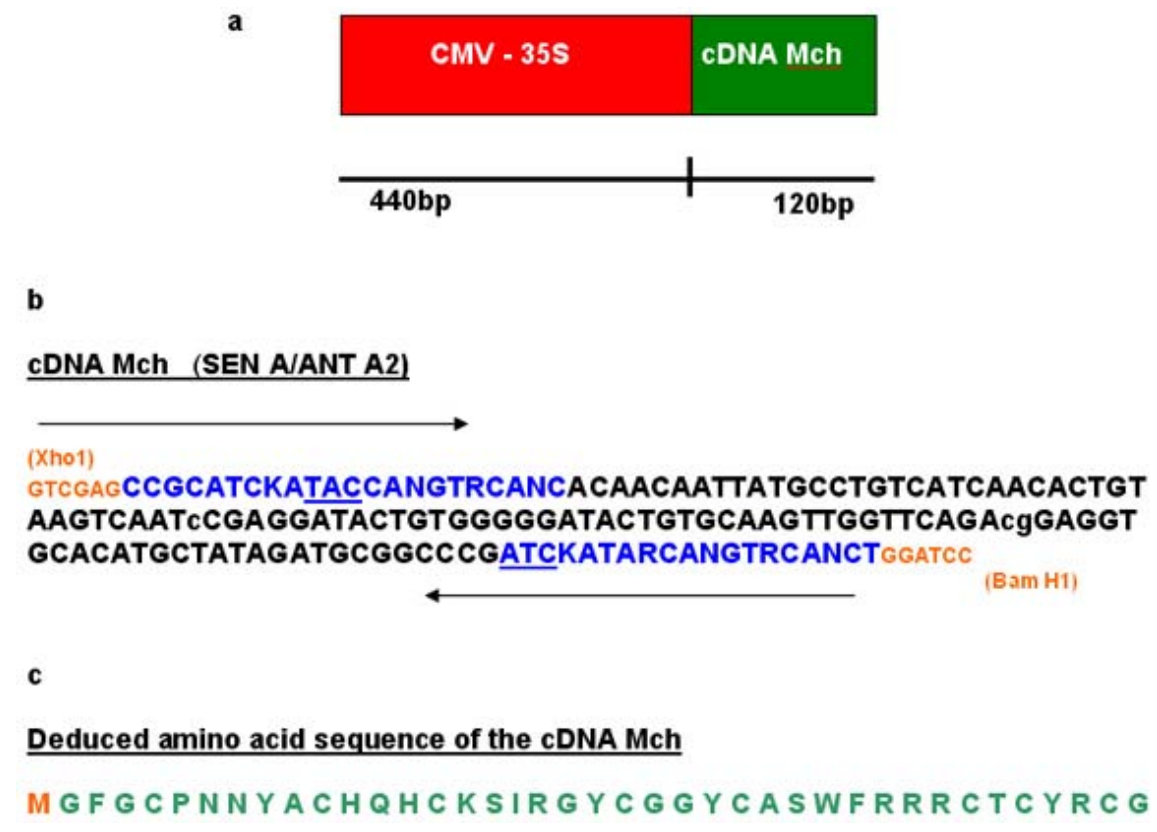

Figure 2.

(a) Diagram of the structure and the specificity of the defensin-like insert in the PBinAR vector.

(b) Nucleotide sequence of the defensin-like gene: underlined the beginning and end of the ORF (blue: primers; black: ORF).

(C) Amino acid sequence of the defensin-like peptide.

performed using $A$. tumefaciens-directed gene transfer essentially as described (Fillatti et al. 1987).

\section{Presence of the defensin-like gene in transgenic plants}

Plants in tissue culture were kept under a 16-h light/8-h dark period on Murashige and Skoog medium (Murashige and Skoog, 1962) supplemented with $2 \%(\mathrm{w} / \mathrm{v})$ sucrose at $22^{\circ} \mathrm{C}$. In the greenhouse the plants were grown in potting compost soil at $22^{\circ} \mathrm{C}$ during the light period (16 hrs) and $15^{\circ} \mathrm{C}$ during the dark period $(8 \mathrm{hrs})$. Leaves were used for genomic DNA extraction to confirm the presence of the defensin-like transgene using specific primers directed

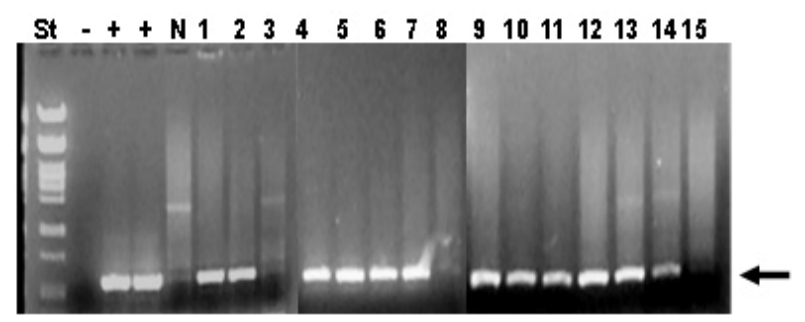

Figure 3. Presence of Mytilus edulis chilensis defensin-like gene in putative transgenic plants. Leaf genomic DNA was amplified by PCR using the primers described in Figure 1. The arrow indicates the expected size of the fragment (560 bp). Lanes: St, bp size standard; (-), no DNA in the amplification reaction; (+), PCR amplification of the chimeric gene-containing plasmid used to transform plant cells. $\mathrm{N}$, non-transformed controls; 1 -15, transgenic tobacco plant lines: lines 3,8 and 15 were not transformed. either towards the cauliflower mosaic virus promoter $35 \mathrm{~S}$ (5'-gCA CgA CAC gCT TgT CTA C-3') or towards the defensin-like gene sequence (Defl: 5'-CgC ATC gAT AgC Agg $\mathrm{TgC}$ AC-3'). The resulting amplicon had the expected bp size.

\section{Expression of the defensin-like gene in transgenic plants}

Northern blots. Total RNA from control and transgenic tobacco plants were resolved in formaldehyde agarose gels and transferred to a nylon membrane (Harms et al. 1998). The membrane was hybridized to a ${ }^{32} \mathrm{P}$-labeled defensinlike probe.

RT PCR. The procedure described by Invitrogen SuperScript III First-Strand Synthesis System for RT-PCR (Cat. No: 18080-051) was used. The usual precautions for avoiding RNA degradation were taken until the reverse transcription reaction was complete. A solution of $10 \mu \mathrm{g}$ total RNA in $9 \mu \mathrm{l}$ of $1 \mathrm{X}$ annealing buffer was prepared and complemented with $1 \mu \mathrm{l}$ of the oligodeoxynucleotide degenerate primer mix $(100 \mathrm{pmol} / \mu \mathrm{l})$. The mix was heated for $3 \mathrm{~min}$ at $65^{\circ} \mathrm{Cand}$ allowed to cool to room temperature. To $10 \mu \mathrm{l}$ of each annealed RNA sample, $15 \mu \mathrm{l}$ of a cDNA synthesis mix was added,allowing the reverse transcriptase reaction to go for $1 \mathrm{hr}$ at $37^{\circ} \mathrm{C}$. The reaction was stopped by heat inactivation for $10 \mathrm{~min}$ at $75^{\circ} \mathrm{C}$. Two $\mu$ of this cDNA mixture was used as a template for each $50 \mu \mathrm{l}$ PCR amplification reaction, following standard procedures. 


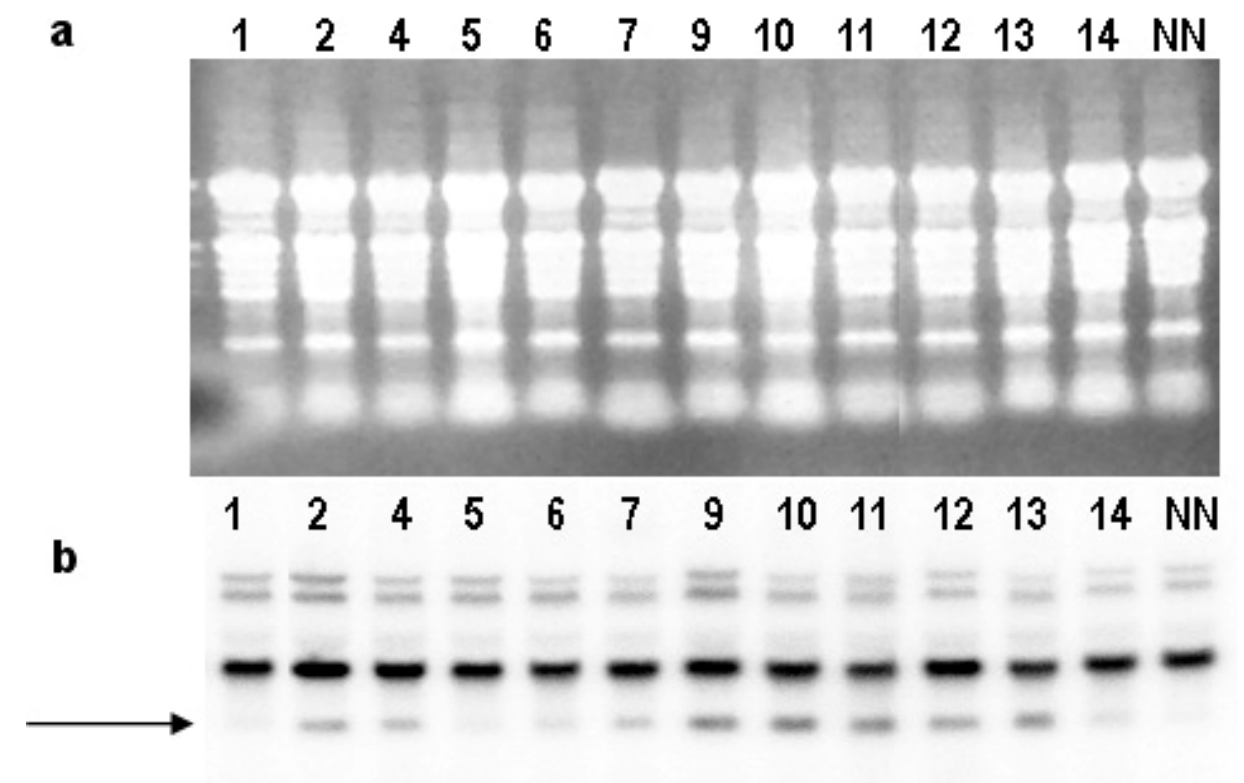

Figure 4. Expression of the defensin-like transgene in transformed whole tobacco plants.

(a) Agarose-formaldehyde gel stained with ethydium bromide.

(b) Northern blot analysis. Arrow indicates the expected position of the hybridization band specific for the defensin-like probe. Total RNA from 12 independent lines (lanes 1-14) were analysed. Lanes 2, 4, and 6-14 were considered positive lines. NN = Control, corresponding to non transformed plants.

Western blots. Total proteins from control and transgenic tobacco plants were determined by the bicinchoninic acid kit (Sigma Co. USA, B 9643), resolved in a 10\% Laemmli PAGE-SDS gel, and transferred to a nitrocellulose membrane. The membrane was then exposed to a $1 / 5000$ dilution of the polyclonal antibody MGD1, elicited in rabbits against a Mytilus defensin (Mitta et al. 1999) as the first antibody followed by an incubation with an HRPlabelled anti rabbit $\operatorname{IgG}$ fraction and developed with DAB (Towbin et al. 1979).

\section{Challenge with Pseudomonas syringae pv. syringae}

Leaves from transgenic and control tobacco were infiltrated by mechanical injury with the phytopathogen Pseudomonas syringaepv. syringaeat a concentration of approximately $10^{5-1} 10^{6} \mathrm{CFU} / \mathrm{ml}$ in $10 \mathrm{mM} \mathrm{MgCl}_{2}$ (Bi et al. 1995). Putative protective effect was measured by naked-eye observation after 2-7 days post-infection.

\section{RESULTS}

\section{Generation of the MCh-Def clone}

Figure 1 shows the DNA insert corresponding to the defensin-like ORF from Mytilus edulis chilensis. This was subcloned into the $\mathrm{pBinAR}$ plant tissue expression vector as shown in Figure 2.

\section{Detection of the defensin-like transgene in} transformation-positive tobacco plants

PCR. As shown in Figure 2, a set of primers specifically directed against the construct should resolve only transformation-positive clones which contain the whole

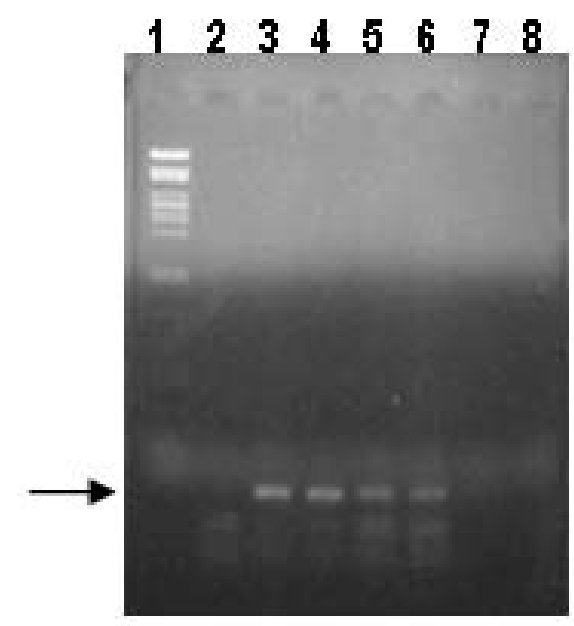

Figure 5. Expression of the defensin-like transgene in tobacco plantsleaf tissue. Ethidium bromide stained agarose gel resolving the RT-PCR reactions of four of the selected positive lines shown in Figure 4 (lines 9 - 12). Lanes: 1, Pst1-digested lambda DNA; 2, no template control reaction; 3-6, positive lines 9-12; 7-8, two untransformed lines. Arrow indicates the expected amplicon size. 
transgene when amplification occurs using primers against the flanking regions of the 35S-CaMV promoter from pBinAR (a) and from the defensin-like gene (b). Figure 3 shows that 12 out of 15 putative transformed lines amplify a $560 \mathrm{bp}$ band corresponding to the whole construct when leaf genomic DNA from transformed and non transformed plants were amplified using the fore mentioned primers. Genomic DNA from tobacco leaves either from plants transformed with $M C h-D e f$ construct (lanes 1-15) as well as non transformed controls (N) was amplified using the standardized primers described in Figure 1.

Northern Blot. Selected lines, grown under axenic conditions, were the source for total RNA extraction in order to detect the putative transcript from the defensin-like transgene. Figure $4 \mathrm{a}$ shows the stained profile of the material resolved on the agarose gel, while Figure 3 shows the result of the transferred material hybridized to the defensin-like specific probe. Ten out of the 12 selected lines gave different degree of hybridization to the probe indicating differential transcription in the lines which correspond to the expression of MCh-Def gene (lanes 2, 4 and 6-14, respectively).

RT PCR. In order to reconfirm the results from Northern blot analysis, four out of the seven transcription positive lines were selected to evaluate specific transcription on leaf tissue which will be the target of challenging with pathogen bacteria. Figure 5 shows the RT-PCR results, confirming that lines 9-12 do express the defensin-like transgene.

Western Blot. Further, in order to detect recombinant peptide in the selected lines, crude protein extracts of leaves were resolved on denaturant gels, transferred to a nitrocellulose membrane and exposed to a defensin-like specific antibody (Figure 6).

\section{Challenge with Pseudomonas pv. syringae and evaluation of resistance}

Transgenic as well as control tobacco leaves were infected with $P$. syringae to evaluate the degree of resistance provided by the expressed defensin-like transgene. Figure 7 shows the degree of damage observed.

\section{DISCUSSION}

There have been a number of attempts to use both heterologous and even homologous peptides as tools to increase disease-resistance in transgenic plants (for a review, see Castro and Fontes, 2005). Although most of them have been unsuccessful,some of them have been inspiring in the search for new alternatives (Sharma et al. 2000; Kanzaki et al. 2002; Ponti et al. 2003). Some of the reasons for the lack of success in the past have been estimated to be due to either a low level of expression of the transgene (Halpin, 2005), a putative inactivation of the gene product by constitutive proteases in the new host environment, or a low half-life of the expressed peptide in the host plant (Owens and Heutte, 1997).

In this report, the use of a vector containing the defensinlike ORF from Mytilus edulis chilensis in frame with the $35 \mathrm{~S}$ promoter from the cauliflower mosaic virus (Figure 2) allowed us to get an $80 \%$ efficiency of transformation and a reasonable good expression which offers a detectable, protection to tobacco leaves when challenged with Pseudomonas syringae pv. syringae. We selected 12 positive transgene lines containing the $M$. edulis chilensis defensin-like cDNA to demonstrate disease-resistance (Figure 3). Notwithstanding not all tissues of the positive lines either had the transgene and/or express it. Northern blot analysis indicated that only 7 out of 12 independent transgenic lines gave a significant expression and one of them, a faint one (Figure 4, lanes 2, 4, and 9-13). We selected lines 9-12 to further verify RNA expression in leaves of the transgenic plants, the target of our challenging test. Indeed all four positive lines gave significant transcription of the transgene (Figure 5). Additionally, the

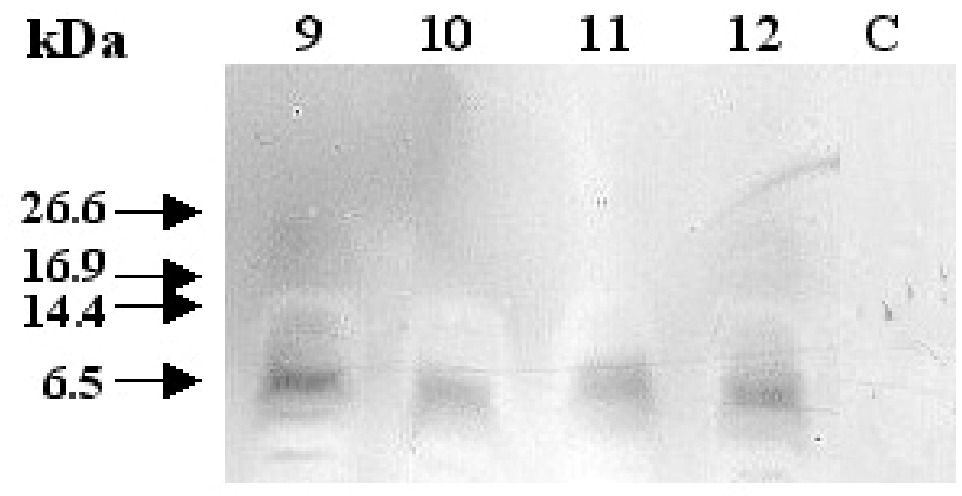

Figure 6. Western blot analysis of non-challenged crude extracts from leaves of the selected transgenic lines 9-12, shown in Figure 5, using polyclonal antibodies against Mytilus defensin. Protein load, $30 \mu \mathrm{g} / \mathrm{lane}$. Lane $\mathrm{C}$ corresponds to an untransformed tobacco plant as control. 


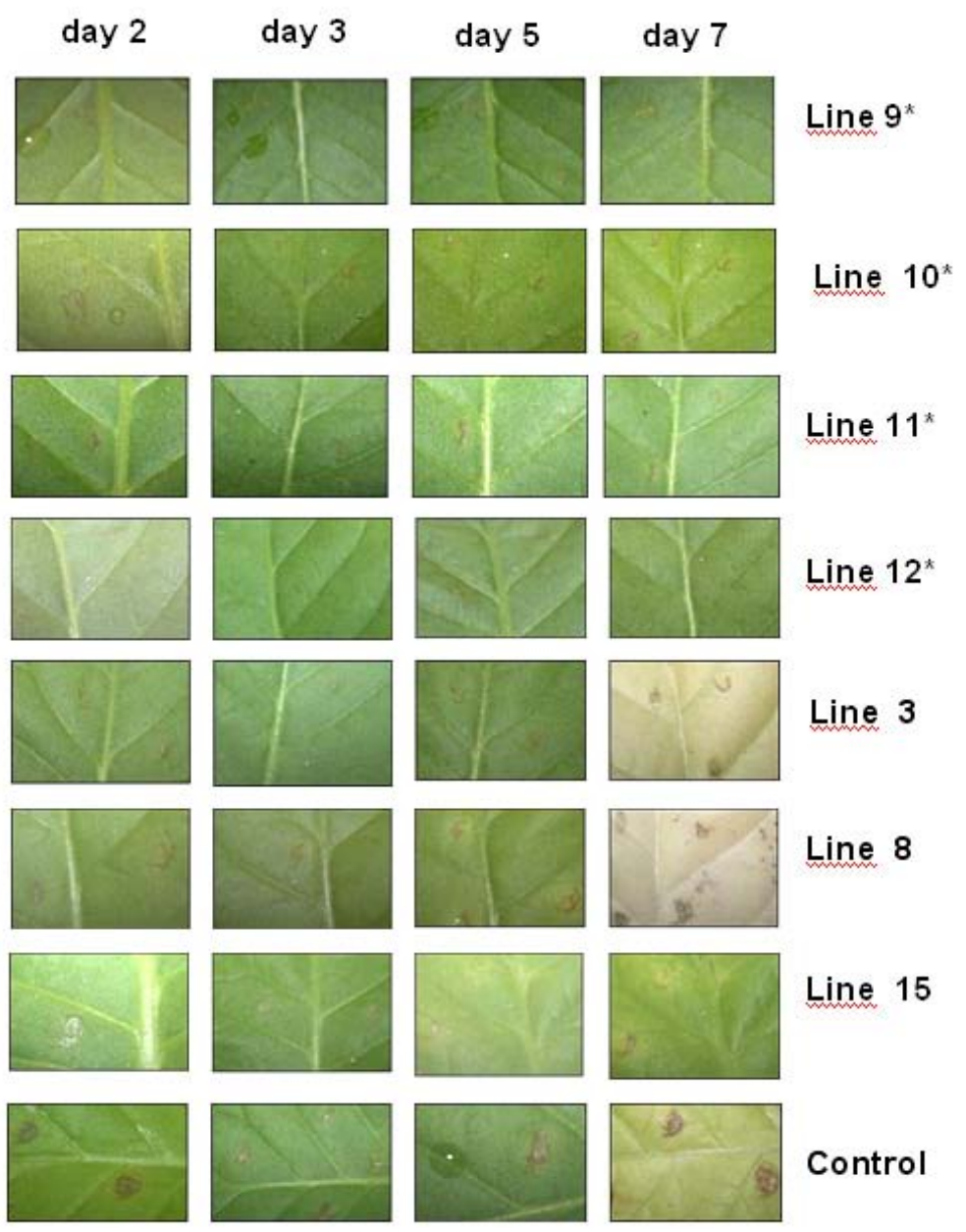

Figure 7. Tobacco leaves infiltrated by mechanical injury with the phytopathogen Pseudomonas syringaepv. syringaeat a concentration of approximately $10^{5-10^{6}} \mathrm{CFU} / \mathrm{ml}$. Observation after 2-7 days post-infection indicates a putative protective effect for lines 9,10,11 and especially $12\left(^{*}\right)$, particularly evident at day 7 with respect to control leaves. Lines $3,8,15$ are transformed nonexpressing lines. Control leaves were derived from non-transformed plants. The figure is one of two identical duplicates.

protein was expressed in all four lines (Figure 6), providing a strong argument to support the resistance to infection shown by challenged leaves measured by two unequivocal parameters: number and/or size of the lesions observed (Figure 7). In this frame, protective responses were detected in the positive lines up to 7 days post-challenge, well above to those described for other peptides in previous works on tobacco plants (Okamoto et al. 1998; Koo et al. 2002; Li et al. 2001).

These positive preliminary results are encouraging. Considering that the transgene product is a defensin-like molecule expressed in a system which has natural counterparts (Castro and Fontes, 2005), endogenous proteases do not consider it a target. In addition, the transgene product could act synergistically with endogenous AMPs, natural defensins and/or alike, which might explain the observed protective effect over challenging in selected transgenic lines. Because endogenous defensins are expressed in minute amounts in tobacco leaves, over-expression of the transgene, even under non-challenged conditions, transforms it in a helperlike tool to overcome putative encounters with aggressive pathogens.

In conclusion, this report is a contribution to further design strategies to evaluate the impact of family-related peptides in commercially relevant plant species which might be optimized through their enhanced disease-resistance potential.

\section{REFERENCES}

ACKERMANN, Mark R.; GALLUP, Jack M.; ZABNER, Joseph; EVANS, Richard B.; BROCKUS, Charles W.; MEYERHOLZ, David K.; GRUBOR, Branka and BROGDEN, Kim A. Differential expression of sheep betadefensin-1 and -2 and interleukin 8 during acute Mannheimia haemolytica pneumonia. Microbial Pathogenesis, July 2004, vol. 37, no. 1, p. 21-27. 
BARDAN, A.; NIZET, V. and GALLO, R.L. Antimicrobial peptides and the skin. Expert Opinion on Biological Therapy, April 2004, vol. 4, no. 4, p. 543-549.

BI, Yong-Mei; KENTON, Paul; MUR, Luis; DARBY, Robert and DRAPER, John. Hydrogen peroxide does not function downstream of salicylic acid in the induction of PR protein expression. Plant Journal, August 1995, vol. 8, no. 2, p. 235-245.

BROEKAERT, Willem F.; TERRAS, Franky R.G.; CAMMUE, Bruno P.A. and OSBORN, Rupert W. Plant defensins: novel antimicrobial peptides as components of the host defense system. Plant Physiology, August 1995, vol. 108 , no. 4 , p. 1353-1358.

BROEKAERT, Willem F.; CAMMUE, Bruno P.A.; DE BOLLE, M.F.C.; THEVISSEN, K.; DE SAMBLANX, G.W. and OSBORN. Rupert W. Antimicrobial peptides from plants. Critical Reviews in Plant Science, 1997, vol. 16, no. 3, p. 297-323.

CASTRO, Mariana S. and FONTES, Wagner. Plant defense and antimicrobial peptides. Protein and Peptide Letters, January 2005, vol. 12, no. 1, p. 11-16.

CHARLET, Maurice; CHERNYSH, Serguey; PHILIPPE, Hervé; HETRU, Charles; HOFFMANN, Jules A. and BULET, Philippe. Innate immunity: isolation of several cysteine-rich antimicrobial peptides from the blood of a mollusc, Mytilus Edulis. Journal of Biological Chemistry, September 1996, vol. 271, no. 36, p. 21808-21813.

CHIANG, C.C. and HADWIGER, L.A. The Fusarium solani-induced expression of a pea gene family encoding high cysteine content proteins. Molecular Plant-Microbe Interactions, July-August 1991, vol. 4, no. 4, p. 324-331.

DEBLAERE, R.; BYTEBIER, B.; DE GREVE, H.; DEBOECK, F.; SCHELL, J.; VAN MONTAGU, M. and LEEMANS, J. Efficient octopine Ti plasmid-derived vectors for Agrobacterium-mediated gene transfer to plants. Nucleic Acids Research, July 1985, vol. 13, no. 13, p. 47774788.

EPPLE, Petra; APEL, Klaus and BOHLMANN, Holger. ESTs reveal a multigene family for plant defensins in Arabidopsis thaliana. FEBS Letters, January 1997, vol. 400, no. 2, p. 168-172.

FILLATTI, JoAnne J.; KISER, John; ROSE, Ronald and COMAI, Luca. Efficient transfer of a glyphosate tolerance gene into tomato using a binary Agrobacterium Tumefaciens vector. Nature Biotechnology, July 1987, vol. 5, no 7, p. 726-730.

HALPIN, Claire. Gene stacking in transgenic plants - the challenge for 21 st century plant biotechnology. Plant Biotechnology Journal, March 2005, vol. 3, no. 2, p. 141155.
HARMS, Karsten; RAMIREZ, Ingrid and PEÑACORTÉS, Hugo. Inhibition of wound-induced accumulation of allene oxide synthase transcripts in flax leaves by aspirin and salicylic acid. Plant Physiology, November 1998, vol. 118, no. 3, p. 1057-1065.

HAUG, Tor; STENSVAG, Klara; OLSEN, Ørjan M.; SANSDALEN, Erling and STYRVOLD, Olaf B. Antibacterial activities in various tissues of the horse mussel, Modiolus modiolus. Journal of Invertebrate Pathology, February 2004, vol. 85, no. 2, p. 112-119.

HUANG, Y.; NORDEEN, R.O.; DI, M.; OWENS, L.D. and. MCBEATH, J.H. Expression of an Engineered Cecropin Gene Cassette in Transgenic Tobacco Plants Confers Disease Resistance to Pseudomonas syringae pv. Tabaci. Phytopathology, May 1997, vol. 87, no. 5, p. 494499.

HUBERT, F.; VAN DER KNAPP, W.; NOËL, T. and $\mathrm{ROCH}, \mathrm{P}$. Cytotoxic and antibacterial properties of Mytilus galloprovincialis, Ostrea edulis and Cassostrea gigas (bivalve molluscs) hemolymh. Aquatic Living Resources, 1996, vol. 9, no. 2, p. 115-124.

INGHAM, A.B.; SPROAT, K.W.; TIZARD, M.L.V. and MOORE, R.J. A versatile system for the expression of nonmodified bacteriocins in Escherichia coli. Journal of Applied Microbiology, March 2005, vol. 98, no. 3, p. 676683.

KANZAKI, H.; NIRASAWA, S.; SAITOH, H.; ITO, M.; NISHIHARA, M.; TERAUCHI, R. and NAKAMURA, I. Over-expressing of the wasabi defensin gene confers enhanced resistance to blast fungus (Magnaporthe grisea) in transgenic rice. Theoretical and Applied Genetics, November 2002, vol. 105, no. 6-7, p. 809-814.

KOO, Ja Choon; CHUN, Hyun Jin; PARK, Hyeong Cheol; KIM, Min Chul; KOO, Yoon Duck; KOO, Seong Cheol; OK, Hyun Mi; PARK, Soo Jeong; LEE, Sung-Ho; YUN, Dae-Jin; LIM, Chae Oh; BAHK, Jeong Dong; LEE, Sang Yeol and CHO, Moo Je. Over-expression of a seed specific hevein-like antimicrobial peptide from Pharbitis nil enhances resistance to a fungal pathogen in transgenic tobacco plants. Plant Molecular Biology, October 2002, vol. 50, no. 3, p. 441-452.

LI, Qingshun; LAWRENCE, Christopher B.; XING, HongYan; BABBITT, Ruth A.; BASS, W. Troy; MAITI, Indu B. and EVERETT, Nicholas P. Enhanced disease resistance conferred by expression of an antimicrobial magainin analog in transgenic tobacco. Planta, March 2001, vol. 212, no. 4 , p. 635-639.

MARSHALL, S.H. and ARENAS, G. Antimicrobial peptides: a natural alternative to chemical antibiotics and a potential for applied biotechnology. Electronic Journal of Biotechnology [online]. 15 December 2003, vol. 6, no. 3, p. 1-14. Available from Internet: 
http://www.ejbiotechnology.info/content/vol6/issue3/full/1/ index.html. ISSN 07173458.

METLITSKAIA, Luba; CABRALDA, Jennifer E.; SULEMAN, Dinar; KERRY, Cynthia; BRINKMAN, Jacquelyn; BARTFELD, Daniel and GUARNA, M. Marta. Recombinant antimicrobial peptides efficiently produced using novel cloning and purification processes. Biotechnology and Applied Biochemistry, June 2004, vol. 39, no. 3, p. 339-345.

MITTA, G.; VANDENBULCKE, F.; HUBERT, F. and $\mathrm{ROCH}, \mathrm{P}$. Mussel defensins are synthesised and processed in granulocytes then released into the plasma after bacterial challenge. Journal of Cell Science, December 1999, vol. 112 , no. 23, p. 4233-4242.

MITTA, Guillaume; VANDENBULCKE, Franck and $\mathrm{ROCH}$, Philippe. Original involvement of antimicrobial peptides in mussel innate immunity. FEBS Letters, December 2000, vol. 486, no. 3, p. 185-190.

MORENO, M.; SEGURA, A. and GARCÍA-OLMEDO, F. Pseudothionin-St1, a potato peptide active against potato pathogens. European Journal of Biochemistry, July 1994, vol. 223, no. 1, p. 135-139.

MURASHIGE, T. and SKOOG, F. A revised medium for rapid growth and bioassays with tobacco tissue cultures. Physiologia Plantarum, 1962, vol. 15, p. 473-497.

OKAMOTO, M.; MITSUHARA, I.; OHSHIMA, M.; NATORI, S. and OHASHI, Y. Enhanced expression of an antimicrobial peptide sarcotoxin IA by GUS fusion in transgenic tobacco plants. Plant and Cell Physiology, January 1998, vol. 39, no. 1, p. 57-63.

OTVOS Jr, Laszlo. Antibacterial peptides isolated from insects. Journal of Peptide Science, October 2000, vol. 6, no. 10, p. $497-511$.

OWENS, Lowell D. and HEUTTE, Thomas M. A single amino acid substitution in the antimicrobial defense protein cecropin B is associated with diminished degradation by leaf intercellular fluid. Molecular Plant-Microbe Interactions, May 1997, vol. 10, no. 4, p. 525-528.

PENNINCKX, A.M.A.; EGGERMONT, K.; TERRAS, F.R.G.; THOMMA, B.P.H.; DE SAMBLANX, G.W.; BUCHALA, A.; METRAUX, J.-P.; MANNERS, J.M. and BROEKAERT, W.F. Pathogen-induced systemic activation of a plant defensin gene in Arabidopsis follows a salicylic acid-independent pathway. Plant Cell, December 1996, vol. 8 , no. 12 , p. 2309-2323.

PONTI, D.; MANGONI, M.L.; MIGNOGNA, G.; SIMMACO, M. and BARRA, D. An amphibian antimicrobial peptide variant expressed in Nicotiana tabacum confers resistance to phytopathogens. Biochemical Journal, February 2003, vol. 370, no. 1, p. 121-127.
ROCHA-SOSA, Mario; SONNEWALD, Uwe; FROMMER, Wolf; STRATMANN, Marina; SCHELL, Jeff and WILMITZER, Lothar. Both developmental and metabolic signals activate the promoter of a class I patatin gene. EMBO Journal, January 1989, vol. 8, no. 1, p. 23-29.

SHARMA, Arun; SHARMA, Rashmi; IMAMURA, Morikazu; YAMAKAWA, Minoru and MACHII, Hiroaki. Transgenic expression of cecropin B, an antibacterial peptide from Bombyx mori, confers enhanced resistance to bacterial leaf blight in rice. FEBS Letters, October 2000, vol. 484 , no. 1 , p. $7-11$.

TERRAS, F.R.G.; EGGERMONT, K.; KOVALEVA, V.; RAIKHEL N.V.; OSBORN, R.W.; KESTER, A.; REES, S.B.; TORREKENS, S.; VAN LEUVEN, F.; VANDERLEYDEN, J.; CAMMUE, B.P.A and BROEKAERT, W.F. Pseudothionin-St1, a potato peptide active against potato pathogens. Plant Cell, May 1995, vol. 7 , no. 5, p. 573-588.

TINCU, J. Andy and TAYLOR, Steven W. Antimicrobial peptides from marine invertebrates. Antimicrobial Agent and Chemotherapy, October 2004, vol. 48, no. 10, p. 36453654.

TOSSI, Alessandro. Host defense peptides: roles and applications. Current Protein and Peptide Science, February 2005, vol. 6, no. 1, p. 1-3.

TOWBIN, Harry; STAEHELIN, Theophil and GORDON, Julian. Electrophoretic transfer of proteins from polyacrilamide gels to nitrocellulose sheats: Procedure and some applications. Proceedings of the National Academy of Sciences USA, September 1979, vol. 76, no. 9, p. 43504354.

WU, Hua; ZHANG, Guolong; MINTON, Ernest J.; ROSS, Christopher R. and BLECHA, Frank. Regulation of cathelicidin gene expression: induction by lipopolysaccharide, interleukin-6, retinoic acid, and Salmonella enterica serovar typhimurium infection. Infection and Immunity, October 2000, vol. 68, no. 10, p. 5552-5558.

YEAMAN, Michael R. and YOUNT, Nannette Y. Mechanisms of antimicrobial peptide action and resistance. Pharmacological Reviews, March 2003, vol. 55, no. 1, p. 27-55.

ZASLOFF, Michael. Antimicrobial peptides of multicellular organisms. Nature, January 2002, vol. 415, no. 6870 , p. 389-395. 